\title{
Mediastinal Germ Cell Tumor T2 TNM Finding
}

National Cancer Institute

\section{Source}

National Cancer Institute. Mediastinal Germ Cell Tumor T2 TNM Finding. NCI Thesaurus. Code C146836.

Mediastinal germ cell tumor infiltrating contiguous organs or accompanied by malignant effusion. (WHO Classification of Tumors of the Lung, Pleura, Thymus and Heart, 2015) 